\title{
Is Hormonal Treatment of Congenital Undescended Testes Justified? A Debate
}

\author{
Faruk Hadziselimovic \\ Cryptorchidism Research Institute, Kindermedizinisches Zentrum, Liestal, Switzerland
}

\section{Keywords}

Cryptorchidism · Hormonal treatment · Mini-puperty ·

Orchidopexy

\begin{abstract}
Abnormal germ cell development in cryptorchidism is not a result of a congenital dysgenesis but is preceded by a hormone imbalance and perturbation in germ cell-specific gene expression during abrogated mini-puberty. Adequate treatment with low doses of GnRHa enables $86 \%$ of men to achieve a normal sperm count and, most importantly, prevent development of azoospermia. GnRHa treatment induces a significant transcriptional response, including protein coding genes involved in pituitary development, the hypothalamicpituitary-gonadal axis, and testosterone synthesis. Furthermore, hormonal treatment to achieve epididymo-testicular descent as a first choice of treatment of cryptorchidism has a long tradition in Europe. It eliminates the necessity of subsequent surgery. Moreover, in the cases of non-responders it facilitates orchidopexy and contributes considerably to a reduced incidence of unilateral and the more serious bilateral complete post-surgical testicular atrophy.
\end{abstract}

(C) 2019 S. Karger AG, Basel

Cryptorchidism represents the most frequent causes of azoospermia in man [Fedder et al., 2004]. The estimated frequency of azoospermia in the normal population is

\section{KARGER}

(C) 2019 S. Karger AG, Basel

E-Mail karger@karger.com

www.karger.com/sxd
$0.4 \%$ (3/711) [Itoh et al., 2001], while non-obstructive azoospermia was found 25 times more often in unilateral and 80 times more often in bilateral cryptorchidism [Hadziselimovic et al., 2011a]. Of note, the number of patients who developed azoospermia or severe oligospermia is the same in patients who had surgery before and after the first year of age ( $p=0.39$, Fisher's Exact test) [reviewed by Verkauskas et al., 2016]. Consequently, in cryptorchidism severe infertility and azoospermia develop irrespective of the age the treatment was administered [Hadziselimovic and Herzog, 2001; Hadziselimovic et al., 2011a]. Thus, early and successful orchidopexy ultimately does not improve fertility, because it fails to address the underlying pathophysiological cause that is a defective mini-puberty [Hadziselimovic and Herzog, 2001]. During abrogated mini-puberty, insufficient LH secretion results in reduced Leydig cell capacity and a low testosterone plasma level, culminating in impaired Ad spermatogonia development [Hadziselimovic et al., 2005]. It has been shown that the transformation of gonocytes into $\mathrm{Ad}$ spermatogonia is a testosterone-dependent process [Zivkovic et al., 2006], and if this transformation fails during infancy, infertility is inevitable [Hadziselimovic and Herzog, 2001; Hadziselimovic et al., 2007; Kim et al., 2008]. Half of the patients presenting with unilateral cryptorchidism and the majority of those presenting with bilateral cryptorchidism belong to the so-called high infertility risk (HIR) group [Bilius et al., 2015]. The goal of treating cryptorchidism is to achieve normal fertility, which is

Prof. Faruk Hadziselimovic

Cryptorchidism Research Institute

Kindermedizinisches Zentrum, University of Basel

$\mathrm{CH}-4410$ Liestal (Switzerland)

E-Mail Praxis@ kindermedizin-zentrum.ch 
largely dependent on a functioning mini-puberty and, as a result, the presence of Ad spermatogonia in prepubertal testes [Hadziselimovic et al., 2005].

\section{Is Cryptorchidism an Endocrinopathy?}

In 1975, pronounced Leydig cell atrophy starting in early infancy was described as evidence to support endocrinopathy as an etiological factor in cryptorchidism [Hadziselimovic et al., 1975]. A failed testosterone surge in the second postnatal month was observed in preterm infants in whom cryptorchidism was diagnosed at 18 months post term [Baker et al., 1988]. Thus, preterm infants with undescended testes appear to be similar in this respect to fullterm cryptorchid infants [Gendrel et al., 1978]. Except for a blunted testosterone response to human chorionic gonadotropins (HCG), there is no evidence of altered steroidogenesis in cryptorchid testes prior to puberty [reviewed in Jockenhovel and Swerdlow, 1989]. Furthermore, lower LH plasma values or lower LH response by gonadotropin-releasing hormone $(\mathrm{GnRH})$ was demonstrated several times [Gendrel et al., 1977; Jacobelli et al., 1979; Mazzi et al., 1979; Bollerslev et al., 1986; Job et al., 1987; Hamza et al., 2001]. In addition, a cohort of cryptorchid boys lacking Ad spermatogonia showed low basal and stimulated gonadotropin plasma values that are compatible with those found in cases of hypogonadotropic hypogonadism [Hadziselimovic et al., 1979; Verkauskas et al., 2016]. Of importance, the first morning void urine highlights gonadotropin deficiency better than plasma values do. Both LH and FSH first morning void urine values were significantly lower in cryptorchid boys when compared to age-matched controls [Hadziselimovic, 1987]. Therefore, the cause of the lower testosterone response seems to be at both the pituitary and hypothalamic level.

\section{Paternity as a Fertility Indicator?}

Lee and co-authors, who performed a retrospective review of medical records and sent a detailed questionnaire to patients, concluded that unilateral cryptorchid men have a normal paternity rate [Lee et al., 1996]. It should be noted that in this study the authors did not rely upon the results of testicular biopsies. Consequently, the condition of testicular tissues and, importantly, the presence of Ad spermatogonia were not assessed. The patients were considered to be cryptorchid solely on the fact that they had surgery. Therefore, the inevitable inclusion of low in-

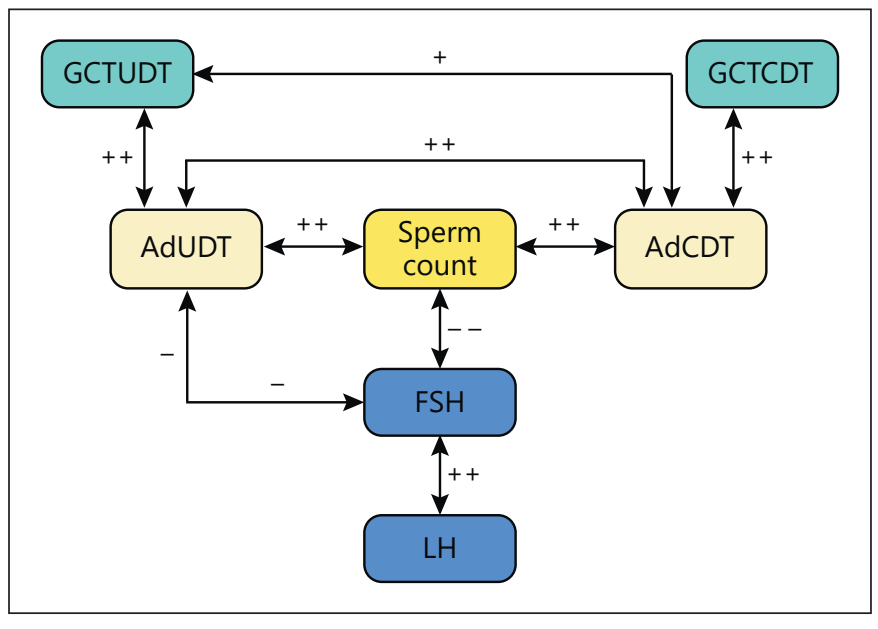

Fig. 1. Schematic model presenting a dominant role of Ad spermatogonia in predicting fertility outcome and the importance of plasma FSH levels. ++/--, strong correlation; +/-, significant correlation. AdCDT (scrotal testis) is the best predictor of future fertility. AdUDT (undescended testis) is a decisive factor for supporting an FSH negative feedback mechanism. GCTUDT (total germ cell count in undescended testis) and GCTCDT (total germ cell count in scrotal testis) have no direct influence either on the sperm count or on the plasma FSH level.

fertility risk (LIR) patients and misdiagnosed cases of retractile testes, all of them having an excellent fertility outcome, distort the results. Thus, paternity alone is not a good fertility indicator. More importantly, only testicular biopsy can reliably determine which patients will likely become infertile and could therefore benefit from hormonal therapy. This means that the rationale behind a testicular biopsy is both diagnostic and therapeutic. Testicular biopsy is even more justified as it allowed the detection of in situ carcinoma occurring in $0.5 \%$ of cryptorchid boys [Hadziselimovic et al., 1997].

\section{Sperm Count and Long-Term Follow-Up Studies}

A total of $47.5 \%$ of unilateral and $78 \%$ of bilateral cryptorchid males had their sperm concentration in the infertility range according to WHO standards [Hadziselimovic at al., 2005]. Severely decreased sperm counts and no age-related differences were found in the HIR group of cryptorchid men, indicating that successful orchidopexy is insufficient to prevent the development of infertility and azoospermia [Hadziselimovic et al., 2005]. When transformation into Ad spermatogonia had occurred (indicating functional mini-puberty), age-related differenc-
4
Sex Dev 2019;13:3-10 DOI: $10.1159 / 000496418$
Hadziselimovic 


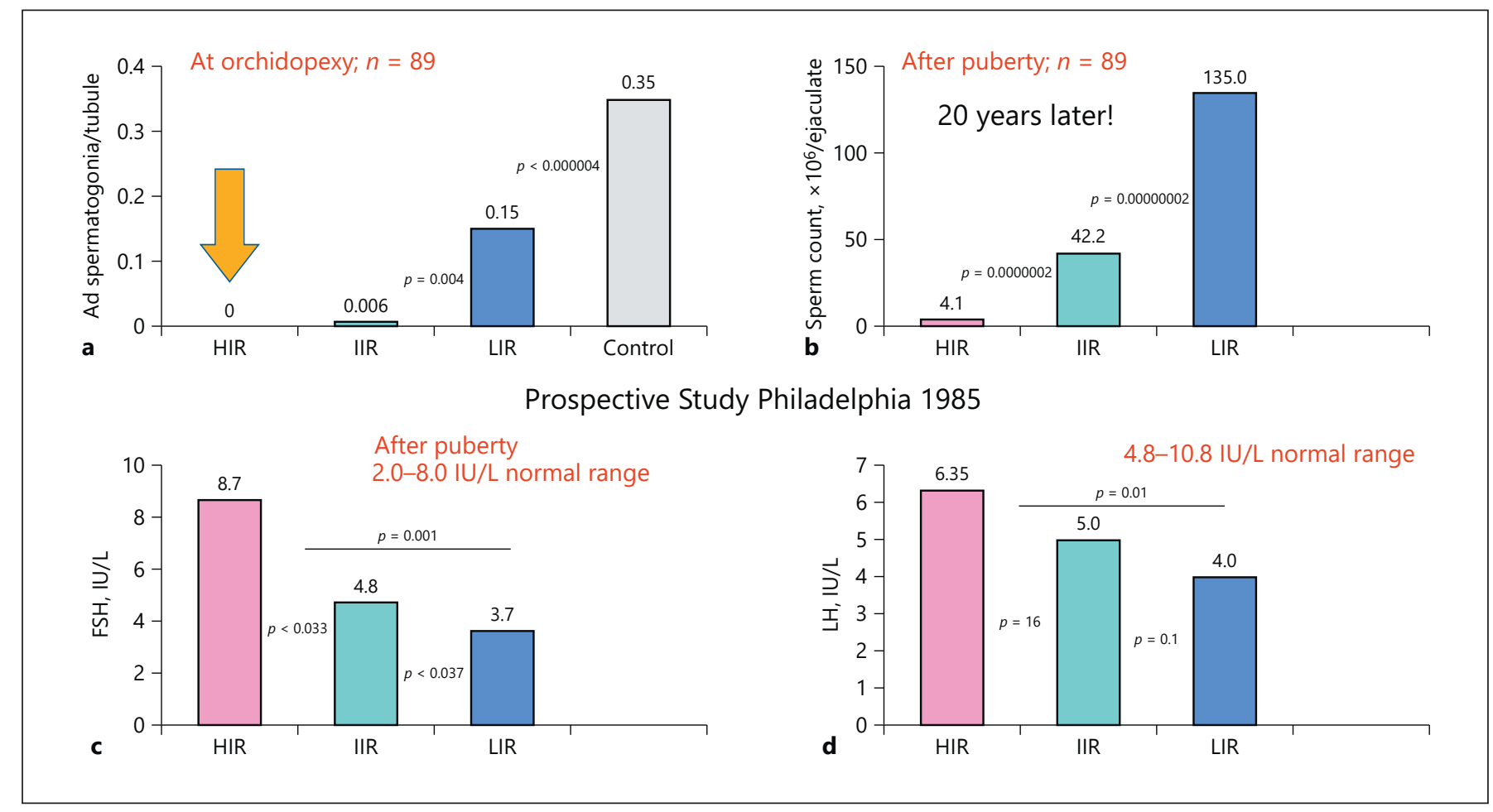

Fig. 2. a Values of Ad spermatogonia vary among the high-infertility-risk (HIR) $(-/-, n=18)$, intermediate-infertility-risk (IIR) $(-/+, n=46)$, and low-infertility-risk (LIR) $(+/+, n=25)$ groups. In the IIR group, Ad spermatogonia were always present in the scrotal testis. The lowest germ cell count was observed in the HIR (-/-) group and the highest (although still lower than controls) was observed in the LIR $(+/+)$ group. b Sperm count in the 3 different infertility risk groups. c Analysis of plasma FSH levels in relation to the presence of Ad spermatogonia in the 3 different infertility risk groups. Ad -/-: HIR $(n=18)$; Ad -/+: IIR $(n=46)$; and Ad +/+: LIR $(n=24)$. FSH normal range: 2-8 IU/L. d The LIR patients with the healthiest histology have LH levels in the hypogonadotropic range, while the 2 other groups have normal LH values despite more severe testicular pathology, indicating a relative LH deficiency. LH normal range: 4.8-10.8 IU/L.

es in the fertility outcome were observed. The younger the unilateral cryptorchid boys were at surgery, the higher their sperm count was when they reached adulthood. However, although the difference in the sperm count of boys younger than 3 years at surgery (median $156 \times 10^{6}$ / ejaculate) versus boys older than 8 years (median $87 \times$ $10^{6}$ /ejaculate) is statistically significant, it is biologically irrelevant [Hadziselimovic et al., 2005]. Both groups had a total sperm count within the normal range [Hadziselimovic et al., 2005]. The results of a 20-year long-term prospective study designed in 1985 in Philadelphia by the late John Duckett and Faruk Hadziselimovic were in accordance with our previous study from 2005, underscoring the importance of an intact hypothalamus-pituitarygonadal (HPG) axis for fertility development in cryptorchid men [Hadziselimovic et al., 2005; Hadziselimovic and Hoecht, 2008]. Sperm concentrations correlated to the number of Ad spermatogonia found at the time of orchidopexy ( $p<0.001)$ : $80 \%$ of males in the HIR group (lacking Ad spermatogonia) were oligospermic and 20\% showed azoospermia [Hadziselimovic and Hoecht, 2008]. In patients with unilateral cryptorchidism, $70 \%$ of scrotal testes showed different degrees of impaired transformation of Ad spermatogonia, indicating that cryptorchidism is a bilateral disease. Furthermore, correlations between testicular histology and post-pubertal hormone levels confirmed a relative gonadotropin deficiency in the majority of adult cryptorchid men (Fig. 1). The most critical factor for the development of infertility is the finding that gonadotropin levels show a more significant correlation with the presence or absence of Ad spermatogonia in both gonads than with unilateral or bilateral undescended testes (Fig. 2) [Hadziselimovic and Hoecht, 2008].
Hormonal Treatment of Congenital Undescended Testes
Sex Dev 2019;13:3-10 DOI: $10.1159 / 000496418$ 


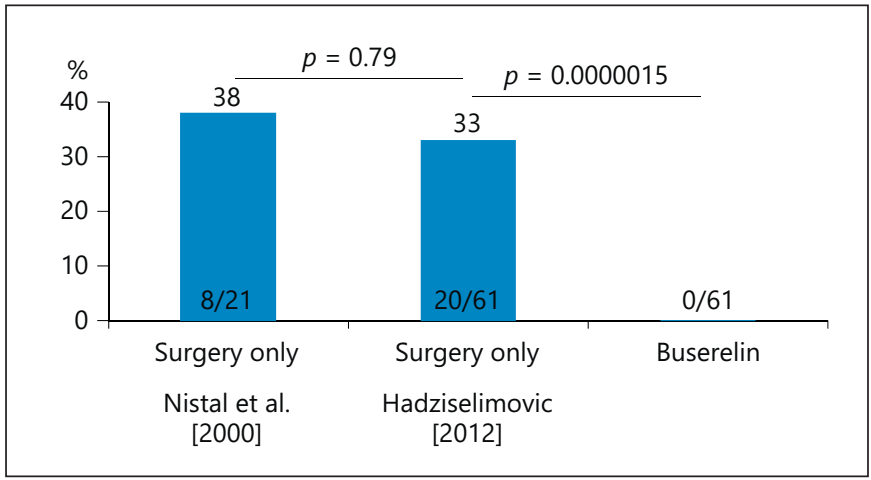

Fig. 3. Incidence of azoospermia in high infertility risk groups. Two surgery-only groups, [38\%, $n=8 / 20$; Nistal et al., 2000, and $33 \%, n=20 / 61$; Hadziselimovic et al., 2007] are compared to a group in which surgery was followed by 6 months of buserelin treatment [ $n=0 / 50$; Hadziselimovic, 2008].

In boys with a high risk of infertility, adequate treatment with low doses of GnRHa enabled $86 \%$ of the men to achieve a normal sperm count and, most importantly, not a single patient developed azoospermia. This strongly contrasts with the results of the 'surgery-only' group where no patient showed a normal sperm count and $20 \%$ were diagnosed with azoospermia [Hadziselimovic, 2008] (Fig. 3).

\section{RNA Profiling Data Support Hormonal Treatment}

RNAseq analysis of a new group of HIR and LIR patients, which were selected using identical histological criteria, confirmed and extended our previous results obtained with GeneChip hybridization [Hadziselimovic et al., 2009, 2011b]. Nearly all of the genes implicated in the HPG axis that were reported to be downregulated in the HIR group were confirmed by our RNA-seq analysis. The reproducibility of the gene sets downregulated in either study of cryptorchid boys (with defective mini-puberty and lack of Ad spermatogonia) clearly supports a role for the HPG axis in the development of azoospermia and infertility.

In 2016 we reported decreased PROK2, CHD7, FGFR1, and SPRY4 gene expression in the HIR group of cryptorchid boys with impaired LH secretion [Hadziselimovic et al., 2016]. Mutations of each of the 4 genes results in the development of Kallmann syndrome [Valdes-Socin et al., 2014; Kim, 2015]. Of note, EGR4, which is involved in regulating the secretion of $\mathrm{LH}$, was virtually not expressed in the HIR group [Hadziselimovic et al., 2009]. Several transcripts involved in pituitary development and differentiation like ISL1, OTX2, PITX1, PITX2, GATA2, LHX2, LHX6, and LHX8 had a lower signal in the HIR group. As a paralog, ISL1 is related to $L H X 4$ by duplication within the genome and subsequently it evolved a new function. LHX4 encodes a member of a large protein family which contains the LIM domain, a unique cysteine-rich zinc-binding domain. The encoded protein is a transcription factor involved in the control of the pituitary gland development. Furthermore, deletion of OTX1 was found in 6 subjects with genitourinary defects. Three of these individuals were diagnosed with cryptorchidism [Jorgez et al., 2014]. Otx2 heterozygous male mice display compromised fertility (reduced LH levels and testicular weight) due to a defect in the development, number, and migration of $\mathrm{GnRH}$ neurons [Larder et al., 2013]. Otx1 and Otx2 are functionally similar and play interchangeable roles [Acampotra et al., 1999]. OTX2 could compensate for OTX1 deficiency at levels that vary among individual patients. GnRHa treatment boosts the expression of certain genes that were found to have a reduced expression in HIR patients and also increases the expression of their family members, e.g., the DLX family members DLX1/3/6 and EGR family members EGR2 and EGR3; ISL2, NR4A2, OTX1, and OTX2, the listed POU class family members, PR domain containing genes, RUNX1 and RUNX2, SIX2 and SIX3, as well as LEP, PCSK1, and TAC3, and finally the SOX family. Interestingly, lower signals of long noncoding RNAs (lncRNAs) participating in epigenetic processes, including AIRN, FENDRR, XIST, and HOTAIR, were found in the HIR group. These data are consistent with the hypothesis that hypogonadotropic hypogonadism in boys with altered mini-puberty is the consequence of a profoundly altered gene expression program involving protein-coding genes and lncRNAs [Hadziselimovic et al., 2017].

\section{Germ and Sertoli Cell Gene Stimulation by GnRH Treatment}

Four genes (DMRTC2, PAX7, BRACHYURY/T, and $T E R T)$ were associated with defective mini-puberty, had decreased expression in HIR, and were responsive to GnRHa [Gegenschatz-Schmid et al., 2017]. Additionally, the markers $P A X 7, E G R 2, N R G 1$, and NRG3 seem to represent an alternative pathway that is activated by GnRHa and is involved in the gonocyte-to-Ad spermatogonia transition. Furthermore, EGR2, ETV5, ID4, TSPAN8, and $T / B R A C H Y U R Y$ are all regulated by FGF/GDNF signal-
6
Sex Dev 2019;13:3-10 DOI: $10.1159 / 000496418$
Hadziselimovic 


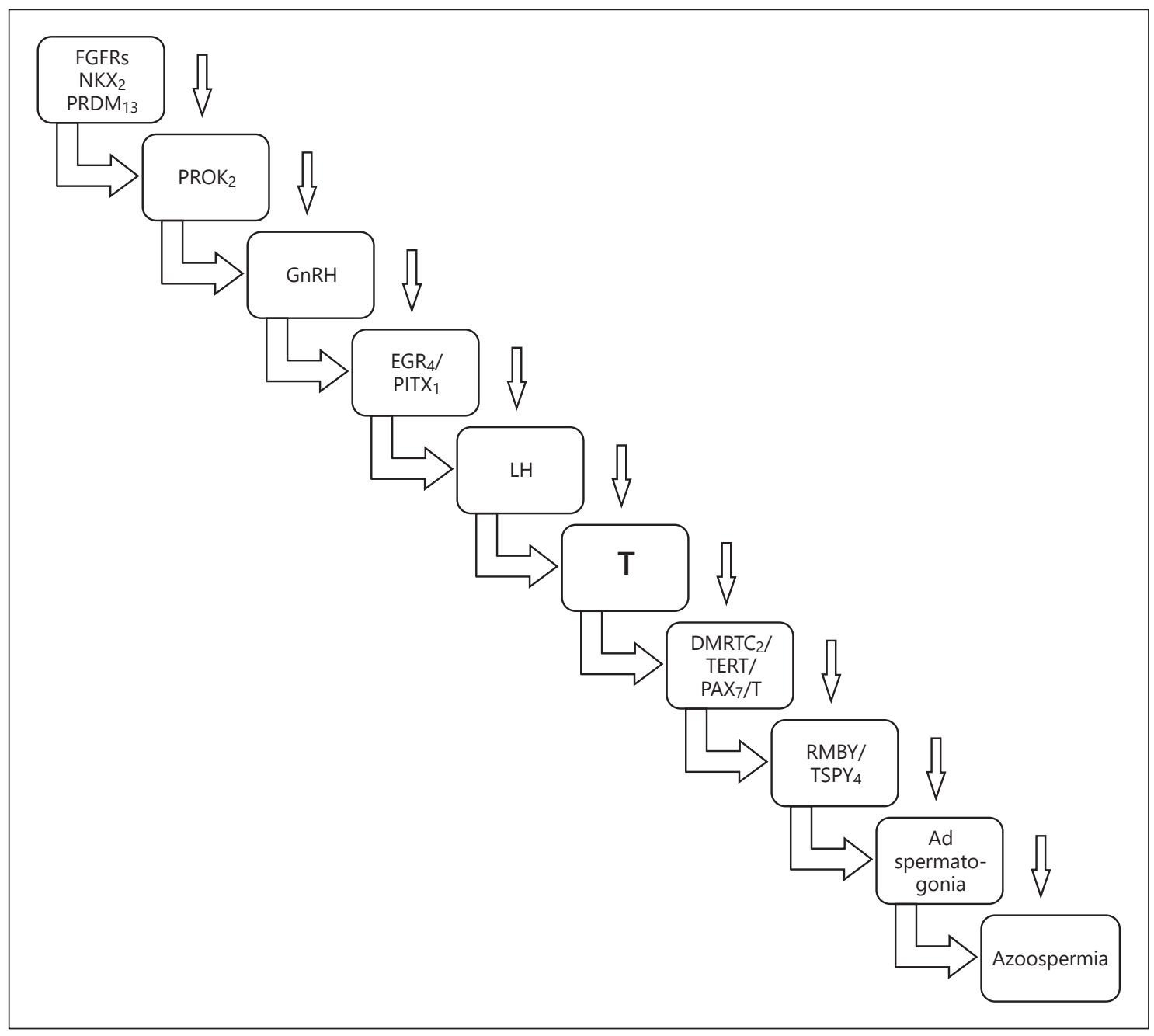

Fig. 4. Pathophysiology of azoospermia development in cryptorchidism. Impaired PROK2 gene signaling induces GnRH and LH deficiency as controlled by the LH-regulators EGR4 and PITX1, resulting in Leydig cell atrophy, decreased testosterone secretion, and abrogated Ad spermatogonia development.

ing, while FOXO1, KIT, NANOS2, NRG1, NRG3, and $P A X 7$ expressions are regulated by retinoic acid [Gegenschatz-Schmid et al., 2017]. The HIR group showed decreased transcription of CYP26B1 [Hadziselimovic et al., 2009], which is known to be responsible for spermatogenesis and, via retinoid signaling, the determination of germ cell fate in mice [Bowles et al., 2006]. Of interest, 4 genes localized in the male-specific $\mathrm{Y}$ region, $R B M Y 1 B, R B$ $M Y 1 E, R B M Y 1 J$, and TSPY4, show reduced mRNA levels in HIR samples and also positively responded to GnRHa treatment. This observation supports data of global conservations of the epigenetic pattern associated with the sequences of the same origin (X-transposed, $\mathrm{X}$-degenerate, and ampliconic) [Gegenschatz-Schmid et al., 2018].
In addition, $P R D M$ genes, some of which are important for primordial germ cell specification and differentiation [PRDM1/BLIMP1, Kobayashi et al., 2017; PRDM14, Shirane et al., 2016] as well as adult meiotic recombination [PRDM9, Smagulova et al., 2016], were differentially expressed in the HIR group [Hadziselimovic et al., 2018]. PRDM9 was the only downregulated gene in the HIR group that was also stimulated by GnRHa treatment. PRDM9 is a downstream effector of testosterone action and is related to testosterone-regulated cell proliferation in classical testosterone target tissues (Fig. 4). Thus, PRDM9 is involved in the establishment of Ad spermatogonia and its perturbation impacts patients afflicted by cryptorchidism. 
Impaired mini-puberty affects Sertoli cell development through positive and negative regulation of morpho-regulatory and apoptotic genes. In contrast to the germ cells, GnRHa treatment had a repressive effect on most Sertoli cell-specific genes, suggesting that Sertoli cells underwent a cellular rearrangement. We propose that gonadotropin-dependent increases in FASLG and $G D N F$ expression drive Sertoli cell proliferation and germ cell self-renewal and support the transition of gonocytes to Ad spermatogonia, independently of inhibin.

In conclusion, EGR4 and PITX1 controlled by PROK2/ CHD7/FGFR1/SPRY4 genes are responsible for LH deficiency, which in turn affects the Ad spermatogonia transitional effectors FGFR3, FGF9, NANOS2, NANOS3, SOHLH1, and SOHLH2. Upon GnRHa treatment, however, alternative pathways are activated, including the LH-secretion orchestrating factors EGR2, EGR3, TAC1, TAC3, PROP1, and LEP and the gonocyte-to-Ad spermatogonia transition effectors DMRTC2, T, PAX7, TERT, NRG1, NRG3, RBMY1B, RBMY1E, and RBMY1J [Hadziselimovic et al., 2016; Gegenschatz-Schmid et al., 2017]. Obtained results indicate novel testosterone-dependent genes and provide valuable insight into the transcriptional response to both defective mini-puberty and curative GnRHa treatment.

\section{Temperature or Transposons?}

In contrast to the general belief that high temperature damages cryptorchid gonads before sexual maturation is completed, recent evidence is consistent with the idea that germ cell loss resulting in infertility due to cryptorchidism is a consequence of alterations in the Piwi pathway and transposon de-repression [Hadziselimovic et al., 2011b, 2015]. Several members of the Tudor gene family and members of the DEAD-box RNA helicase family, together with GTSF1, MEAL, MOV10L1 genes, were found to show significantly lower RNA signals in the HIR group [Hadziselimovic et al., 2011b, 2015]. Positive cytoplasmic antibody staining indicated that the mRNA and protein levels correspond. Patients from the LIR group showed coherently stronger staining for GTSF1 and PIWIL4 proteins and weaker staining for L1 transposon when compared to the HIR samples [Hadziselimovic et al., 2011b, 2015]. These findings provide evidence consistent with the idea that infertility in cryptorchidism is a consequence of alterations in the Piwi pathway and transposon de-repression that are induced by impaired mini-puberty.

\section{Is There a Positive Effect of Hormonal Treatment for Epididymo-Testicular Descent prior to Surgery?}

The developing gonadotropin-releasing hormone system is essential for epididymo-testicular descent and is highly sensitive to reduced fibroblast growth factor (FGF) signaling. Our understanding of the impact of FGFR1 in the process of epididymo-testicular descent has considerably improved [Hadziselimovic et al., 2010]. At later stages of embryonic development, the undifferentiated epididymal mesenchyme is a specific domain for FGFR1 expression. Most individuals with syndromic crypto-epididymis, as well as individuals with isolated non-descent of the epididymo-testicular unit, exhibit some disturbance of FGF, FGFR1 and/or genes involved in HPG axis regulation. However, the mechanisms underlying FGF dysregulation may differ between various syndromes [Hadziselimovic, 2016]. In cryptorchid boys, $\mathrm{GnRH}$ treatment reportedly induces increased testosterone secretion and stimulates further epididymis development and completion of epididymo-testicular descent [Bica and Hadziselimovic, 1993]. Boys with successful descent of the epididymis and testis have a normal-sized epididymis, while the majority of non-responders to hormonal treatment have a small and underdeveloped epididymis [Bica and Hadziselimovic, 1993].

The main reason for not recommending hormonal treatment of the undescended epididymo-testicular union is supposedly that the success rate of this treatment is as low as $20 \%$ [Ritzen et al., 2007]. This statement is misleading because it does not consider the distribution of the positions of the epididymo-testicular unit before treatment. Moreover, all studies quoted against hormonal treatment lack the critical long-term follow-up patient survey. One of the first long-term follow-up open studies showed that 4 years after successful hormonal treatment $65 \%$ of the testes were still descended [Hadziselimovic et al., 1984; Hadziselimovic, 2017]. In 1995, Höcht published a randomized LH-RH versus surgery study including 60 cryptorchid boys aged 2-9 years [Höcht, 1983, 1987]. All patients randomized for the surgery treatment alone had histological changes compatible with cryptorchidism, so it is highly likely that only undescended and not also retractile testes were treated. LH-RH treatment was successful in 59\% of the patients. A long-term study from Waldschmidt and colleagues [1993], who analyzed the descent rate 9 years after treatment, found that $52 \%$ of the testes remained descended. Thus, LH-RH treatment is effective in
8

Sex Dev 2019;13:3-10 DOI: $10.1159 / 000496418$
Hadziselimovic 
Table 1. Descent rate of the epididymo-testicular unit from a prescrotal position treated with gonadotropin-releasing hormone

\begin{tabular}{lll}
\hline & $n$ & Success, \% \\
\hline De Muinck Keizer-Schrama et al. [1986] & $6 / 9$ & 66 \\
Borkenstein and Zobel [1985] & $5 / 9$ & 55 \\
Hagberg and Westphal [1987] & $8 / 17$ & 47 \\
Höcht [1987] & $3 / 4$ & 75 \\
Bica and Hadziselimovic [1993] & $6 / 11$ & 54.5 \\
\hline Total & $28 / 50$ & 56 \\
\hline
\end{tabular}

achieving permanent descent of true cryptorchid testes. Of note, the highest success was achieved when testes were localized in the pre-scrotal position (Table 1).
Table 2. Basel 4-step concept of cryptorchidism treatment

\begin{tabular}{ll}
\hline Step & Treatment \\
\hline 1 & LH-RH $1.2 \mathrm{mg} /$ day for 28 days; if no or partial success: \\
2 & 500 IU hCG/week for 3 weeks; if no descent: \\
3 & Orchidopexy and bilateral biopsy; if no bilateral Ad \\
& spermatogonia: \\
4 & LH-RH $10 \mu \mathrm{g}$ on alternate day for 6 months \\
\hline
\end{tabular}

LH-RH, luteinizing hormone-releasing hormone; hCG, human chorionic gonadotropin

\section{Conclusion}

Abnormal mini-puberty is responsible for the development of infertility in cryptorchidism, and post-surgical hormonal treatment is highly recommended for the high infertility and azoospermia risk group that underwent successful early orchidopexy. Therefore, 2 steps of hormonal treatment currently remain the optimal therapeutic choice (Table 2).

\section{Disclosure Statement}

The author has no conflicts of interest to declare.

\section{References}

-Acampora D, Avantaggiato V, Tuorto F, Barone $\mathrm{P}$, Perera $\mathrm{M}$, et al: Differential transcriptional control as the major molecular event in generating $O t \times 1^{-/-}$and Ot $x 2^{-/-}$divergent phenotypes. Development 126:1417-1426 (1999).

-Baker BA, Morley R, Lucas A: Plasma testosterone in preterm infants with cryptorchidism. Arch Dis Child 63:1198-1200 (1988).

-Bica DT, Hadziselimovic F: Buserelin treatment of cryptorchidism: a randomized, doubleblind, placebo-controlled study. J Urol 148: 617-621 (1992).

Bica DT, Hadziselimovic F: The behavior of epididymis, processus vaginalis, and testicular descent in cryptorchid boys treated with buserelin. Eur J Pediatr. 152(Suppl 2):38-42 (1993).

-Bilius V, Verkauskas G, Dasevicius D, Kazlauskas V, Malcius D, Hadziselimovic F: Incidence of high infertility risk among unilateral cryptorchid boys. Urol Int 95:142-145 (2015).

-Bollerslev J, Rohl H, Krag Sorensen E, Bennet P: Gonadotropin and androgen levels in patients operated upon for cryptorchidism. Dan Med Bull 33:336-338 (1986).

Borkenstein M, Zobel V: Treatment of cryptorchism with LHRH nasal spray. Wien Klin Wochenschr 97:414-416 (1985).

Hormonal Treatment of Congenital Undescended Testes
Bowles J, Knight D, Smith C, Wilhelm D, Richman $\mathrm{J}$, et al: Retinoid signaling determines germ cell fate in mice. Science 312:596-600 (2006).

De Muinck Keizer-Schrama SM, Hazebroek FW, Matroos AW, Drop SL, Molenaar JC, Visser HK: Double-blind, placebo-controlled study of luteinizing-hormone-releasing-hormone nasal spray in treatment of undescended testes. Lancet 1:876-880 (1986).

Fedder J, Crüger D, Oestergaard B, Petersen GB: Etiology of azoospermia in 100 consecutive nonvasectomised men. Fertil Steril 82:14631465 (2004).

Gendrel D, Roger M, Chaussain JL, Canlorbe P, Job JC: Correlation of pituitary and testicular responses to stimulation tests in cryptorchid children. Acta Endocrinol (Copenh) 86:641650 (1977).

Gendrel D, Job JC, Roger M: Reduced post-natal rise of testosterone in plasma of cryptorchid infants. Acta Endocrinol (Copenh) 89:372378 (1978).

Gegenschatz-Schmid K, Verkauskas G, Demougin P, Bilius V, Dasevicius D, et al: DMRTC2, PAX7, BRACHYURY/T and TERT are implicated in male germ cell development following curative hormone treatment for cryptorchidism-induced infertility. Genes 8:267-283 (2017).
Gegenschatz-Schmid K, Verkauskas G, Demougin P, Bilius V, Dasevicius D, et al: Curative GnRHa treatment has an unexpected repressive effect on Sertoli cell specific genes. Basic Clin Androl 28:2 (2018)

Hadziselimovic F: Cryptorchidism, in Retik A, Cukier J (eds): Pediatric Urology, pp 271-281 (Williams \& Wilkins, Baltimore 1987).

Hadziselimovic F: Successful treatment of unilateral cryptorchid boys risking infertility with LH-RH analogue. Int Braz J Urol 34:319-326 (2008).

Hadziselimovic F: Involvement of fibroblast growth factors and their receptors in epididymo-testicular descent and maldescent. Mol Syndromol 6:261-267 (2016).

Hadziselimovic F: On the descent of the epididymo-testicular unit, cryptorchidism, and prevention of infertility. Basic Clin Androl 27:21 (2017).

Hadziselimovic F, Herzog B: The importance of both an early orchidopexy and germ cell maturation for fertility. Lancet 358:1156-1157 (2001).

Hadziselimovic F, Hoecht B: Testicular histology related to fertility outcome and postpubertal hormonal status in cryptorchidism. Klin Pädiatr 219:1-6 (2008). 
Hadziselimovic F, Herzog B, Seguchi H: Surgical correction of cryptorchism at 2 years: electron microscopic and morphometric investigations. J Pediatr Surg 10:19-26 (1975).

Hadziselimovic F, Herzog B, Girard J: Lack of germ cells and endocrinology in cryptorchid boys from one to six years of life, in Bierich JR, Giarola A (eds): Cryptorchidism, pp 129-134 (Academic Press, London 1979).

Hadziselimovic F, Girard J, Herzog B: 4 years' experience with combined hormonal treatment of cryptorchism. Z Kinderchir 39:324-327 (1984).

Hadziselimovic F, Herzog B, Emmons LR: The incidence of seminoma and expression of cell adhesion molecule CD44 in cryptorchid boys and infertile men. J Urol. 157:1895-1897 (1997).

-Hadziselimovic F, Zivkovic D, Bica DT, Emmons LR: The importance of mini-puberty for fertility in cryptorchidism. J Urol 174:15361539 (2005).

-Hadziselimovic F, Hoecht B, Herzog B, Buser MW: Infertility in cryptorchidism is linked to the stage of germ cell development at orchidopexy. Horm Res 68:46-52 (2007).

Hadziselimovic F, Hadziselimovic NO, Demougin P, Krey G, Hoecht B, Oakeley EJ: EGR4 is a master gene responsible for fertility in cryptorchidism. Sex Dev 3:253 -263 (2009).

Hadziselimovic F, Hadziselimovic NO, Demougin P, Oakeley EJ: Testicular gene expression in cryptorchid boys at risk of azoospermia. Sex Dev 5:49-59 (2011a).

-Hadziselimovic F, Hadziselimovic NO, Demougin P, Krey G, Oakeley EJ: Deficient expression of genes involved in the endogenous defense system against transposons in cryptorchid boys with impaired mini-puberty. Sex Dev 5:287-293 (2011b).

Hadziselimovic F, Hadziselimovic NO, Demougin P, Krey G, Oakeley E: Piwi-pathway alteration induces LINE-1 transposon derepression and infertility development in cryptorchidism. Sex Dev 9:98-104 (2015).

-Hadziselimovic F, Gegenschatz-Schmid K, Verkauskas G, Docampo-Garcia MJ, Demougin $\mathrm{P}$, et al: Gene expression changes underlying idiopathic central hypogonadism in cryptorchidism with defective mini-puberty. Sex Dev 10:136-146 (2016).

Hadziselimovic F, Gegenschatz-Schmid K, Verkauskas G, Demougin P, Bilius V, et al: GnRHa treatment of cryptorchid boys affects genes involved in hormonal control of the HPG axis and fertility. Sex Dev 11:126-136 (2017).
Hadziselimovic F, Cathomas G, Verkauskas G, Dasevicius D, Stadler MB: Histone methyltransferase mRNA levels increase in response to curative hormone treatment for cryptorchidism-dependent male infertility. Genes 9:pii:E391 (2018).

- Hadziselimovic NO, de Geyter CH, Demougin P, Oakeley EJ, Hadziselimovic F: Decreased expression of FGFR1, SOS1, RAF1 genes in cryptorchidism. Urol Int 84:353-361(2010).

Hagberg S, Westphal O: Results of combined hormonal and surgical treatment for undescended testis in boys under 3 years of age. A randomized study. Eur J Pediatr 146:38-39 (1987).

-Hamza AF, Elrahim M, Elnagar, Maaty SA, Bassiouny E, Jehannin B: Testicular descent: when to interfere? Eur J Pediatr Surg 11:173176 (2001).

Höcht B: Therapy of prepubertal cryptorchidism. Clinical experiences with LH-RH treatment. Fortschr Med 101:1531-1535 (1983).

Höcht B: LH-RH treatment for cryptorchidism. Randomized study and 10year follow-up results. Eur J Pediatr 146(Suppl 2):44-46 (1987).

-Itoh N, Kayama F, Tatsuki TJ, Tsukamoto T: Have sperm counts deteriorated over the past 20 years in healthy, young Japanese men? Results from the Sapporo area. J Androl 22:4044 (2001).

Jacobelli A, Agostino A, Vecci E, Simeoni A, Ferrantelli M: Studies on the pituitary-testicular axis in boys with cryptorchidism,in Bierich JR, Giarola A (eds): Cryptorchidism, pp 261269 (Academic Press, London 1979).

-Job JC, Toublanc JE, Chaussain JL, Gendrel D, Roger M, et al: The pituitary-gonadal axis in cryptorchid infants and children. Eur J Pediatr 146 Suppl 2:2-5 (1987).

Jockenhovel F, Swerdloff RS: Alterations in steroidogenic capacity of Leydig cells in cryptorchid testis, in Abney TO, Keel BA (eds): The Cryptorchid Testis, pp 36-48 (CRS Press Inc, Boca Raton 1989).

- Jorgez CJ, Rosenfeld JA, Wilken NR, Vangapandu HV, Sahin A, et al: Genitourinary defects associated with genomic deletions in 2p15 encompassing OTX1. PLoS One 9:e107028 (2014).

Kim SH: Congenital hypogonadotropic hypogonadism and Kallmann syndrome: past, present, and future. Endocrinol Metab 30:456466 (2015).

Kim SS, Kolon T, Casale P, Carr M, Zderic SA, et al: The positive predictive value of prepubertal testis biopsy on adult sperm density in patients with bilateral undescended testes. J Urol 179:144-145 (2008).
Kobayashi T, Zhang H, Tang WWC, Irie N, Withey S, et al: Principles of early human development and germ cell program from conserved model systems. Nature 546:416-420 (2017).

- Larder R, Kimura I, Meadows J, Clark DD, Mayo S, Mellon PL: Gene dosage of Otx2 is important for fertility in male mice. Mol Cell Endocrinol 377:16-22 (2013).

Lee PA, O'Leary LA, Songer NJ, Coughlin MT, Bellinger MF, LaPorte RE: Paternity after unilateral cryptorchidism. Pediatrics 98:676-679 (1996).

Mazzi C, Riva LP, Morandi G, Mainini E, Scarsi G, Salaroli AA: Study of cryptorchid subjects. Evaluation of the hypophyseal-testicular axis in the prepubertal period, in Bierich JR, Giarola A (eds): Cryptorchidism, pp 269-278 (Academic Press, London 1979).

Nistal M, Riestra ML, Paniagua R: Correlation between testicular biopsies (prepubertal and postpubertal) and spermiogram in cryptorchid men. Hum Pathol 31:1022-1030 (2000).

Ritzén EM, Bergh A, Bjerknes R, Christiansen P, Cortes D, et al: Nordic consensus on treatment of undescended testes. Acta Paediatr 96: 638-643 (2007).

Shirane K, Kurimoto K, Yabuta Y, Yamaji M, Satoh J, et al: Global landscape and regulatory principles of DNA methylation reprogramming for germ cell specification by mouse pluripotent stem cells. Dev Cell 39:87-103 (2016).

-Smagulova F, Brick K, Pu Y, Camerini-Otero RD, Petukhova GV: The evolutionary turnover of recombination hot spots contributes to speciation in mice. Genes Dev 30:266-280 (2016).

-Valdes-Socin H, Almanza MR, Fernández-Ladreda MT, Debray FG, Bours V, Beckers A: Reproduction, smell, and neurodevelopmental disorders: genetic defects in different hypogonadotropic hypogonadal syndromes. Front Endocrinol (Lausanne) 5:1-8 (2014).

-Verkauskas G, Malcius D, Eidukaite A, Vilimas J, Dasevicius D, et al: Prospective study of histological and endocrine parameters of gonadal function in boys with cryptorchidism. J Pediatr Urol 12:238 (2016).

-Waldschmidt J, Doede T, Vygen I: The results of 9 years of experience with a combined treatment with LH-RH and HCG for cryptorchidism. Eur J Pediatr 152(Suppl 2):34-36 (1993).

Zivkovic D, Bica DG, Hadziselimovic F: Effects of hormonal treatment on the contralateral descended testis in unilateral cryptorchidism. J Pediatr Urol 2:468-472 (2006). 